\title{
Natural and anthropogenic consequences of tropical forest soils in Northern Peru using environmental radionuclides as radiotracers
}

\author{
R. Fujiyoshi, ${ }^{1 *}$ Y. Satake, ${ }^{1}$ T. Sato, ${ }^{1}$ T. Sumiyoshi, ${ }^{1}$ J. Dietz, ${ }^{2}$ R. Zimmermann ${ }^{3}$ \\ ${ }^{I}$ Graduate School of Engineering, Hokkaido University, Sapporo 060-8628, Japan \\ ${ }^{2}$ Max Plank Institute for Biogeochemistry, Jena, Germany \\ ${ }^{3}$ Institute of Botany and Botanical Gardens, University of Hohenheim, Stuttgart, Germany
}

(Received May 13, 2008)

Environmental radionuclides $\left({ }^{40} \mathrm{~K},{ }^{137} \mathrm{Cs},{ }^{210} \mathrm{~Pb},{ }^{226} \mathrm{Ra}\right)$ were determined in soils under semi-arid stands, a transition area from thorn to deciduous forest in El Angolo, and heath stands in the Alto Mayo in Northern Peru in order to elucidate their activity level in soil, and to trace underground environment in remote areas of little anthropogenic intervention. Anthropogenic ${ }^{137} \mathrm{Cs}$ was only found in the uppermost portion of the soils in small amount, whereas the ${ }^{210} \mathrm{~Pb}$ activity was exceptionally high at the soil surfaces in a tropical stand of Alto Mayo. The results suggest a fallout nuclide, ${ }^{210} \mathrm{~Pb}$, having been transported from local source(s) not to be specified yet.

\section{Introduction}

There are not so many places on the earth where anthropogenic intervention has never been encountered so far. In Peru, large parts of the tropical and subtropical forests remain unexplored in the Andes as well as in the Amazon lowlands.

The present German authors have continued ecological and biogeochemical investigation in semiarid forests in El Angolo and also in tropical stands at the west Andean foot-hills (Alto Mayo) in Northern Peru since 2000. ${ }^{1-3}$

The present Japanese authors have investigated depth profiles of environmental radionuclides including fallout nuclides $\left({ }^{137} \mathrm{Cs}\right.$ and $\left.{ }^{210} \mathrm{~Pb}\right)$ in semi-natural forest soils to trace various underground activities. They showed applicability of these nuclides of different origin and of chemical properties as tracers for tracking natural and anthropogenic transition under various temperate stands in Germany and Czech Republic as well as on the campus of Hokkaido University in Sapporo, Japan. ${ }^{4-7}$

The purpose of the this study is to elucidate natural and anthropogenic consequences on tropical forest soils in northern Peru where little intervention by men has been encountered so far using several environmental radionuclides $\left({ }^{40} \mathrm{~K},{ }^{137} \mathrm{Cs},{ }^{210} \mathrm{~Pb}\right.$ and $\left.{ }^{226} \mathrm{Ra}\right)$ as natural tracers.

\section{Experimental}

\section{Location and properties of the site}

Figure 1 shows the location map of investigation sites (El Angolo and Alto Mayo) in Northern Peru.

Site 1 (El Angolo): The study area El Angolo is a game hunting preserve established in 1975 in Cerros de Amotape National Park Region in north-western Peru. ${ }^{8}$
The total area of El Angolo is $650 \mathrm{~km}^{2}$. The soils, which formed from Tertiary and Quaternary sediments, drain poorly. There is a strong correlation between topography and soil type. The soils belong to the vertisol and yermosol groups in which the former sustains the forest biomass. The climate in this region is modified by several factors: the cold marine Humboldt Current and the Andean Cordillera impose an environment that is predominantly sub-arid with clouds and fine precipitation. Seasonal rains occur during DecemberMarch. The vegetation depends on the climate: the predominant species in thorn forests are Acacia macracantha and Prosopis pallida. Ceiba trichistandra is the most conspicuous species in premontane deciduous forests. During the rainy season, the woody vegetation is covered with leaves, giving the appearance of evergreen forest. In contrast, during the long dry season, the shrublike and arboreal vegetation lose their leaves and the grassy stratum becomes dry. Then the region assumes the appearance of a very poor floristic landscape.

Site 2 (Alto Mayo): Alto Mayo Protected Rainforest was established on July 23, 1987. The area is 182,000 ha. There are many environmental problems in this area, such as deforestation, loss of biodiversity and erosion due to disorganized development activities. 2,9 Type and structure of the forest is related to the climate and the edaphic conditions. The stratigraphic composition and the geochronology of the exposed rocks of this area were formed by a sequence of pure marine grey limestone from the Triassic-Jurassic eras with great structural deformations. Lithologically, the area is integrated with sedimentary materials of arenaceous quartz, clay marl and grey limestone. The soil samples in this site were collected in 2002 and also in 2006 by J. DIETZ. The first soil sample was collected from open woodland of dense heath forest. The second

\footnotetext{
*E-mail: fuji@eng.hokudai.ac.jp
} 
ones were taken in the vicinity of a cement plant named "Pacasmayo" in Segunda Jerusalen, Alto Mayo, San Martin, Peru on April 6, 2006. The plant established in the mid 1980's was renovated with increased production under new management after 1998.

\section{Soil sampling}

Sampling in Site 1 (El Angolo) was carried out during the end of the rainy season in March 2006. A soil pit with a size of $(50 \times 50 \times 50$ in $\mathrm{cm})$ was excavated with a shovel so that the soil face would not be disturbed as far as possible. Each soil sample (about $500 \mathrm{~g}$ in wet weight) was collected by hand with every $5 \mathrm{~cm}$ (or much smaller interval in some case) from the uppermost portion down to a depth of $40 \mathrm{~cm}$ in the pit where a tape measure was placed along the profile. The sampling points were selected within an experimental plot of 1 ha which had been protected from any disturbance with a fence since 1988 (Points 1 and 2), at a bank in a small stream near the base camp (Point 3), and at a hilly place with Acacia macracantha in predominant vegetation (Point 4).

In Site 2 (Alto Mayo), all samples were collected by J. DIETZ with the same procedure as in the case of El Angolo. A total of 100 soil samples collected in this study were air-dried in Lima for at least three days. After permission of soil import by the Ministry of Agriculture, Forestry and Fisheries of Japan on Dec. 10, 2004, all the dried samples were transported to our laboratory in Hokkaido University (Sapporo, Japan) where they were disaggregated, sieved through a $2 \mathrm{~mm}$ mesh sieve and kept in plastic bottles for further analyses.

\section{Soil properties}

Table 1 summarized some of the soil properties (dry density, water content, soil organic matter and $\mathrm{pH}$ ) investigated in this study. The amount of soil organic matter (SOM) was estimated by the weight loss on ignition at $450{ }^{\circ} \mathrm{C}$ for 24 hours. Soil $\mathrm{pH}$ was measured in a suspension of each sample (soil/ $\mathrm{H}_{2} \mathrm{O}: 1 / 10$ in weight ratio) after 10 to 30 minutes of mixing.

\section{Activity measurement}

Activity of the dry and homogeneous samples $(100 \mathrm{~g})$ was measured for ${ }^{40} \mathrm{~K},{ }^{137} \mathrm{Cs},{ }^{210} \mathrm{~Pb}$ and ${ }^{226} \mathrm{Ra}$ by gamma-spectrometry with two types of HPGe detector (GEM-25185P and GMX10P, EG\&G Ortec, USA). ${ }^{4}$ Counting time was set to be $1.44 \cdot 10^{5}$ seconds for all the soil samples. Standard reference materials were purchased from the International Atomic Energy Agency (IAEA Soil 6, IAEA-312 and IAEA-327) to evaluate the activity concentration of individual samples form counting data obtained with the same geometry under identical operating conditions. Calibration for each nuclide was carried out periodically, as well as the background checks. Precision of the measurement was estimated by considering pertinent photo-peak areas for both samples and the standards. ${ }^{4}$ All data except for ${ }^{210} \mathrm{~Pb}$ were crosschecked by measuring individual samples with two different detectors.

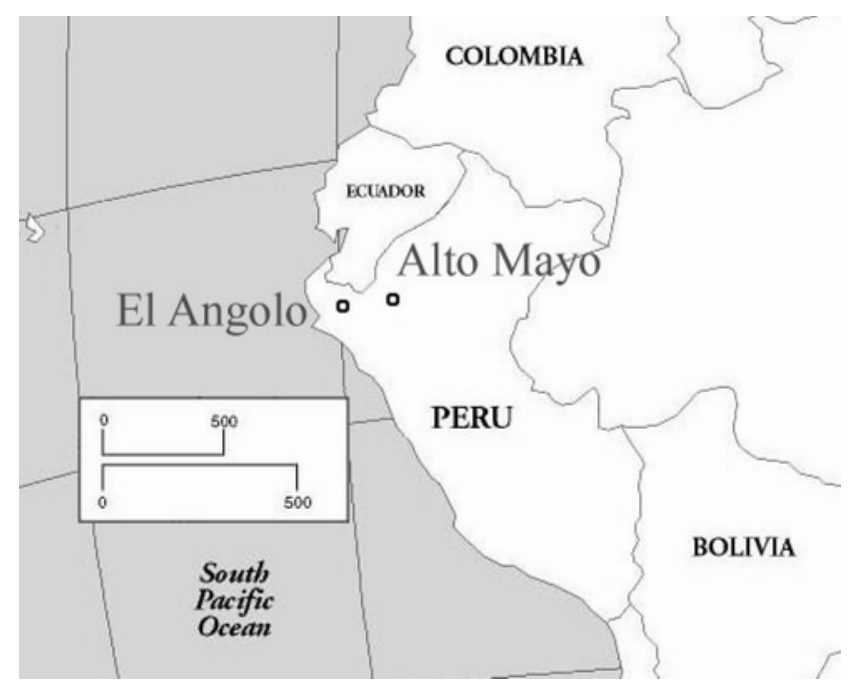

Fig. 1. Location map of studied sites (El Angolo and Alto Mayo) in Northern Peru 
Table 1. Some of the soil properties (in soils collected from Alto Mayo, Peru

\begin{tabular}{|c|c|c|c|c|}
\hline $\begin{array}{c}\text { Site } \\
\text { (Depth, cm) }\end{array}$ & $\begin{array}{c}\text { Dry density, } \\
\mathrm{g} \cdot \mathrm{cm}^{-3}\end{array}$ & $\begin{array}{c}\text { Water content, } \\
\text { wt } \% \\
\end{array}$ & $\begin{array}{c}\text { SOM, } \\
\text { wt } \%\end{array}$ & $\begin{array}{c}\text { Soil } \mathrm{pH} \\
\text { (Soil } 10 \mathrm{~g} \text { in } 1 \mathrm{~L} \text { water) }\end{array}$ \\
\hline \multicolumn{5}{|l|}{ El Angolo } \\
\hline \multicolumn{5}{|l|}{ P1a (Ceiba) } \\
\hline $0-5$ & 1.45 & 18.7 & 8.5 & 6.93 \\
\hline $5-10$ & 1.51 & 17.5 & 8.4 & 7.02 \\
\hline $10-15$ & 1.58 & 17.4 & 8.9 & 6.74 \\
\hline $15-20$ & 1.70 & 16.8 & 8.6 & 6.76 \\
\hline $20-25$ & 1.62 & 15.2 & 8.3 & 6.59 \\
\hline $25-30$ & 1.58 & 15.0 & 8.2 & 6.69 \\
\hline $30-35$ & 1.66 & 13.4 & 7.9 & 6.57 \\
\hline \multicolumn{5}{|l|}{ P1b (Ceiba) } \\
\hline $0-5$ & 1.48 & 15.4 & 8.5 & 7.14 \\
\hline $5-10$ & 1.51 & 17.7 & 9.4 & 6.89 \\
\hline $10-15$ & 1.55 & 17.0 & 9.1 & 6.89 \\
\hline $15-20$ & 1.58 & 15.0 & 8.6 & 6.80 \\
\hline $20-25$ & 1.58 & 14.4 & 8.2 & 6.88 \\
\hline $25-30$ & 1.58 & 14.7 & 8.0 & 6.85 \\
\hline $30-35$ & 1.58 & 12.7 & 7.7 & 6.95 \\
\hline $35-40$ & 1.62 & 10.3 & 7.5 & 6.81 \\
\hline $40-45$ & 1.62 & - & 7.5 & 7.34 \\
\hline \multicolumn{5}{|l|}{ P1c (Ceiba) } \\
\hline $0-5$ & 1.39 & 16.1 & 10.0 & 7.01 \\
\hline $5-10$ & 1.42 & 18.1 & 9.6 & 7.01 \\
\hline $10-15$ & 1.45 & 17.5 & 9.7 & 6.62 \\
\hline $15-20$ & 1.45 & 14.4 & 9.6 & 6.65 \\
\hline $20-25$ & 1.48 & 16.8 & 9.3 & 6.35 \\
\hline $25-30$ & 1.55 & 9.9 & 8.5 & 6.47 \\
\hline $30-35$ & 1.55 & - & 8.1 & 6.36 \\
\hline $35-40$ & 1.58 & 12.4 & - & - \\
\hline \multicolumn{5}{|l|}{ P2 (Young ceiba) } \\
\hline $0-2$ & 1.48 & 13.9 & 7.5 & 6.50 \\
\hline $2-5$ & 1.48 & 10.8 & 8.0 & 6.28 \\
\hline $5-8$ & 1.55 & 13.1 & 7.6 & 6.11 \\
\hline $8-10$ & 1.55 & 7.0 & 7.3 & 5.81 \\
\hline $10-13$ & 1.58 & 12.2 & 6.6 & 5.92 \\
\hline $13-15$ & 1.62 & 11.2 & 6.4 & 5.63 \\
\hline $15-20$ & 1.62 & 14.0 & 6.5 & 5.96 \\
\hline $20-25$ & 1.62 & 10.3 & 7.0 & 6.05 \\
\hline $25-30$ & 1.62 & - & 7.9 & 6.13 \\
\hline \multicolumn{5}{|l|}{ P3 (Alluvial) } \\
\hline $0-5$ & 1.31 & 28.5 & 10.0 & 7.48 \\
\hline $5-10$ & 1.55 & 19.6 & 4.6 & 8.10 \\
\hline $10-15$ & 1.74 & - & 3.1 & 8.30 \\
\hline $15-20$ & 1.70 & 17.2 & 3.1 & 8.46 \\
\hline $20-25$ & 1.70 & 15.7 & 3.0 & 8.53 \\
\hline $25-30$ & 1.70 & 14.0 & 2.8 & 8.65 \\
\hline $30-35$ & 1.70 & 16.6 & 3.2 & 8.41 \\
\hline $35-40$ & 1.70 & 17.2 & 3.3 & 8.54 \\
\hline \multicolumn{5}{|l|}{ P4 (Hill) } \\
\hline $0-1$ & 1.33 & 32.7 & 15.5 & 7.27 \\
\hline $1-3$ & 1.51 & 24.3 & 10.8 & 7.31 \\
\hline $3-5$ & 1.51 & 20.2 & 8.1 & 7.07 \\
\hline $5-7$ & 1.48 & 17.5 & 8.4 & 7.23 \\
\hline $7-10$ & 1.51 & 19.1 & 8.3 & 7.03 \\
\hline $10-12$ & 1.58 & 18.0 & 7.4 & 7.20 \\
\hline $12-15$ & 1.62 & 17.8 & 7.4 & 6.86 \\
\hline $15-20$ & 1.62 & 17.3 & 7.5 & 7.10 \\
\hline $20-25$ & 1.62 & 17.6 & 7.8 & 7.00 \\
\hline $25-30$ & 1.62 & 14.9 & 7.3 & 7.33 \\
\hline $30-35$ & 1.62 & 17.8 & 7.8 & - \\
\hline
\end{tabular}


Table 1. Continued

\begin{tabular}{lcccc}
\hline $\begin{array}{c}\text { Site } \\
\text { (Depth, cm) }\end{array}$ & $\begin{array}{c}\text { Dry density, } \\
\mathrm{g} \cdot \mathrm{cm}^{-3}\end{array}$ & $\begin{array}{c}\text { Water content, } \\
\mathrm{wt} \%\end{array}$ & $\begin{array}{c}\text { SOM, } \\
\mathrm{wt} \%\end{array}$ & $\begin{array}{c}\text { Soil pH, } \\
\text { (Soil 10 g in 1 L water) }\end{array}$ \\
\hline $\begin{array}{c}\text { Moyobamba } \\
\text { Point 5 }\end{array}$ & & & & \\
$0-5$ & & & & \\
$5-10$ & 0.92 & 42.4 & 23.6 & 7.56 \\
$10-15$ & 1.04 & 36.2 & 17.1 & 7.68 \\
$15-20$ & 1.14 & 33.5 & 14.4 & 7.41 \\
Point 6 & 1.12 & 31.8 & 12.6 & \\
$0-5$ & & & & 7.37 \\
$5-10$ & 1.04 & 37.0 & 20.9 & 7.09 \\
$10-15$ & 1.13 & 31.3 & 14.8 & 7.11 \\
$15-20$ & 1.33 & 24.5 & 8.7 & 6.55 \\
$20-25$ & 1.45 & 18.1 & 5.2 & 6.59 \\
Point 7 & 1.51 & 16.9 & 4.6 & 4.64 \\
$0-5$ & & & & 4.48 \\
$5-10$ & 1.31 & 25.7 & 6.0 & 4.46 \\
$10-15$ & 1.33 & 24.9 & 5.5 & 4.40 \\
$15-20$ & 1.36 & 24.0 & 4.6 & 4.51 \\
$20-25$ & 1.45 & 22.3 & 3.6 & 4.42 \\
$25-30$ & 1.48 & 20.6 & 3.0 & 4.54 \\
$30-35$ & 1.45 & 20.8 & 2.9 & 4.49 \\
$35-40$ & 1.42 & 22.7 & 3.6 & \\
\hline
\end{tabular}

Uncertainty of the values may be within $\pm 10 \%, \pm 5 \%$ and $\pm 10 \%$ for dry density, humidity and SOM, respectively.

\section{Results and discussion}

Site 1 (El Angolo)

Generally, the soil in Site 1 was shallow and low in organic content even at the uppermost portion (Table 1). The soils at Points $1 \mathrm{a}, 1 \mathrm{~b}$ and $1 \mathrm{c}$ were collected around a big Ceiba tree which expanded its main roots to three directions from the trunk (Photo 1). Point 2 is adjacent to another young Ceiba tree. The soil at Point 3 was of riverine sediment deposited on the side of a stream near the base camp. It is natural that humidity is the highest of all the soils studied in rainy season (Table 1). The top soil collected on the hill (Point 4) contained much soil organic matter (about 33\%) compared with those in other points.

Activity was measured for all the samples collected in this region. Figure 2 shows depth profiles of ${ }^{40} \mathrm{~K}$ activity concentration of the soils. As is clearly shown from this figure, the riverine sediment (Point 3) was much abundant in radio-potassium which would have been transported as mineral components from the upperstream.

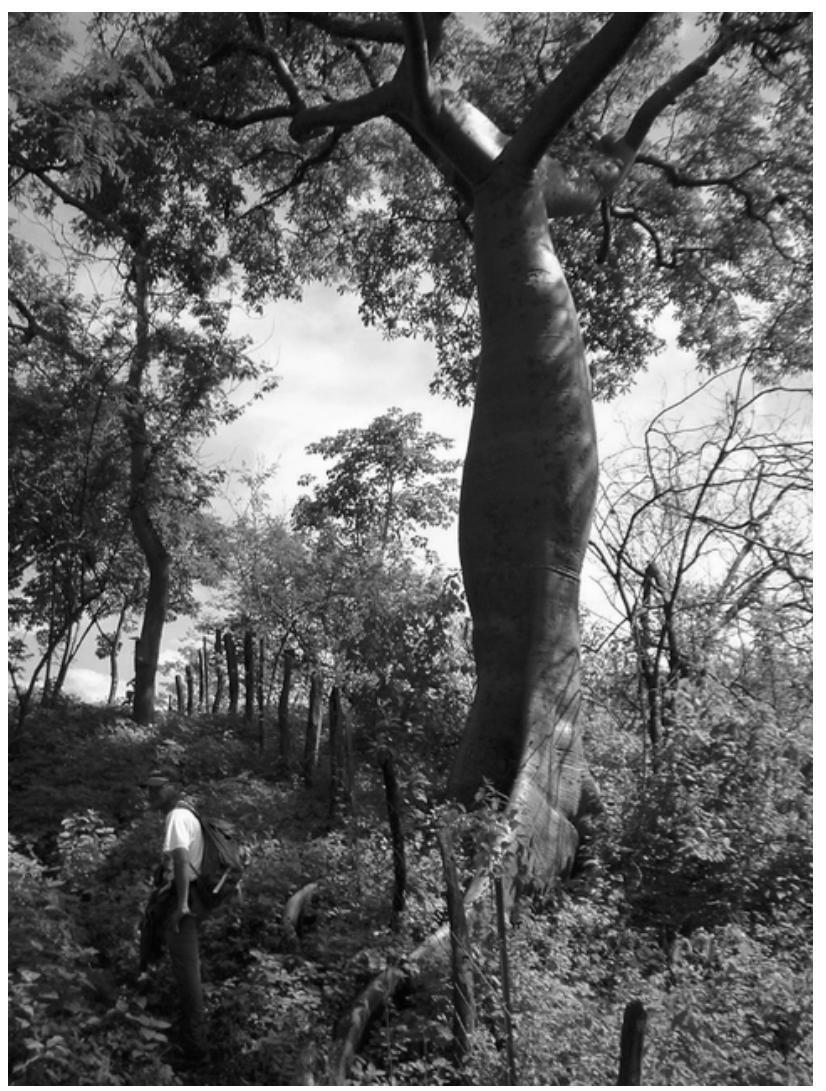

Photo 1. View of a Ceiba tree (Ceiba trichistandra) in El Angolo (Site 1) 


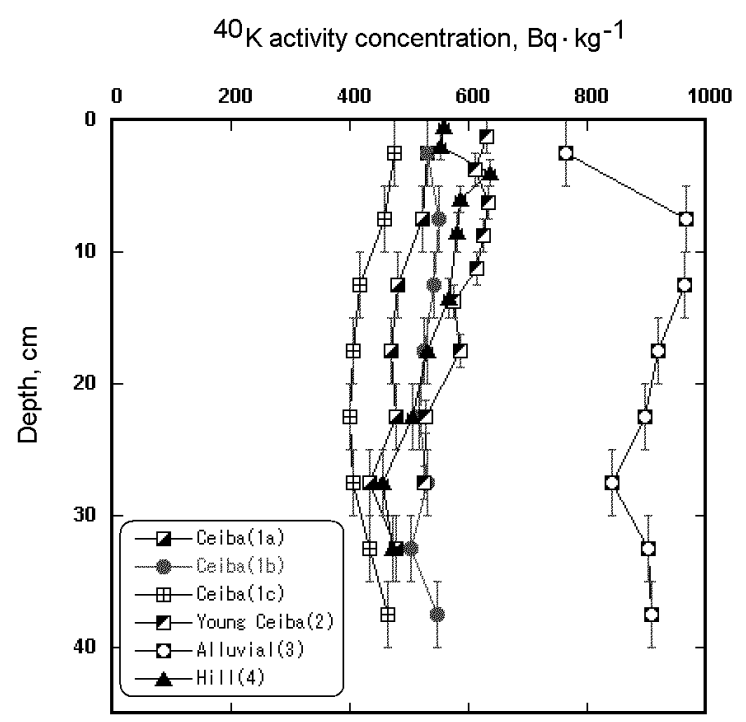

Fig. 2. Depth profiles of ${ }^{40} \mathrm{~K}$ activity concentration in semi-arid soils from El Angolo (Site 1). The soils at Points 1a (Ceiba 1a), 1b (Ceiba 1b) and 1c (Ceiba 1c) were collected around a big Ceiba tree which expanded its main roots to three directions from the trunk. Point 2 (Young Ceiba 2) is adjacent to another young Ceiba tree. The soil at Point 3 (Alluvial 3) was of riverine sediment deposited on the side of a stream near the base house. Another sample was collected at Point 4 (Hill 4) on the hill where vegetation differed distinctly from the other sampling points

Considering the soil in the points P1a, P1b and P1c around a Ceiba tree to be the same in underlying lithology, profiles of ${ }^{40} \mathrm{~K}$ with depth is expected to be virtually the same among them. As shown in Fig. 2, the patterns of the profile are similar to be smooth down to a depth of $40 \mathrm{~cm}$. However, values of ${ }^{40} \mathrm{~K}$ activity concentration were not the same at individual points. It is generally known that radio-potassium distributes rather homogeneously within a horizon of interest, which is a reason for this long-lived natural nuclide having been used as a reference to evaluate distribution of anthropogenic radionuclides like ${ }^{137} \mathrm{Cs}$ in soil. ${ }^{10}$ The authors have not found any reports on ${ }^{40} \mathrm{~K}$ depth profiles around a certain tree to be focused so far. The results may reflect "in situ" biological activity like moving organisms or root uptake of the nutrients like potassium for a long time. Much detailed investigation should be necessary for evaluating present data on a Ceiba tree along with accurate information on biology and ecology there.

Depth profiles of ${ }^{226} \mathrm{Ra}$, another lithogenic nuclide, are shown in Fig. 3. This nuclide as well as ${ }^{40} \mathrm{~K}$ could be an indicator of soil homogeneity within a horizon of interest. ${ }^{4}$ The level of ${ }^{226} \mathrm{Ra}$ activity is similar spatially and vertically around the tree (Points 1a, 1b and 1c), which seems not to be consistent with the result on radio-potassium except for their smooth depth profiles shown in Fig. 2. It may be associated with a fact that the profile of plant available potassium such as ionic $\left(\mathrm{K}^{+}\right)$ and ion-exchangeable forms are different with the bulk profile of potassium, and that bioavailability of radium is different with that of potassium. ${ }^{7}$ In any case, soil horizons around the Ceiba tree are considered to be homogeneous locally with respect to the distribution of both nuclides down to a depth of $40 \mathrm{~cm}$.

As in the case of ${ }^{40} \mathrm{~K}$, the river sediment at Point 3 contains much ${ }^{226} \mathrm{Ra}$ that had been transported by stream water. It should be noted that a minimum value in concentration was observed both in the ${ }^{40} \mathrm{~K}$ and ${ }^{226} \mathrm{Ra}$ profiles about at $25 \mathrm{~cm}$ in depth shown in Figs 2 and 3, respectively. Such a minimum may result from a natural phenomenon which alters transportation rate of rock, sand and mud from the upper stream. For example, a flood transports a great amount and variety of materials down to the stream for a short period of time, which may change the mineral and/or chemical composition of riverine sediments. In contrast, a drought which occurs every half a year finally dries up the stream. Chemical and biological conditions in the river basin must be changed, which leads to alteration of chemical composition of the deposits.

Lead-210 in soil is partly derived naturally from mineral components of the parent rock containing ${ }^{226} \mathrm{Ra}$ and ${ }^{238} \mathrm{U}$, and also anthropogenically from the atmosphere by combustion of fossil fuels. Its profile in soil helps to trace the underground environment as well as soil erosion. ${ }^{11}$ Figure 4 shows the depth profiles of ${ }^{210} \mathrm{~Pb}$ in semi-arid soils in Site 1 around the Ceiba. Surface enrichment of this nuclide appears at most points investigated in this study, which suggests little human intervention like plowing or grazing so far. However, such an exponential decrease in ${ }^{210} \mathrm{~Pb}$ activity concentration with depth could also be disturbed by burrowing organisms like earthworms and moles, or by surface runoff due to heavy rain. Only one point (Point 1b) around the Ceiba tree may have been disturbed at the soil surface down to a depth of $10 \mathrm{~cm}$. It is to be noted that the activity level at the surface portion (30-70 Bq $\left.\mathrm{kg}^{-1}\right)$ was much smaller than those observed in soils under deciduous and coniferous temperate stands in Germany, Czech Republic as well as in Japan (Table 2). $., 5,7$

Cesium-137 is a typical man-made radionuclide with a half life of 30.17 years. A great many studies have already been published on the behavior of this nuclide in various regions in the world. ${ }^{12,13}$ In northern hemisphere, it is known that ${ }^{137} \mathrm{Cs}$ in the environment was derived predominantly from the accident at the Chernobyl nuclear power plant in 1986. There were intensive nuclear bomb tests in the atmosphere in the 1950s and early 1960s on the Pacific Ocean. Approximately $76 \%$ of the fallout nuclides arrived in the Northern Hemisphere and $24 \%$ in the Southern Hemisphere. ${ }^{14}$ The above estimate together with the 
half-life of ${ }^{137} \mathrm{Cs}$ leads to explain that the activity concentration of ${ }^{137} \mathrm{Cs}$ is extremely small (less than $1.5 \mathrm{~Bq} \cdot \mathrm{kg}^{-1}$ ) even at the uppermost portion of the semiarid soil in northern Peru investigated in this study (Fig. 5). However, a study carried out in tropical rainforest soils in southern Costa Rica showed that most of the radiocesium in soil could be attributed to global fallout from atmospheric nuclear weapon tests between 1945 and $1980 .{ }^{15}$

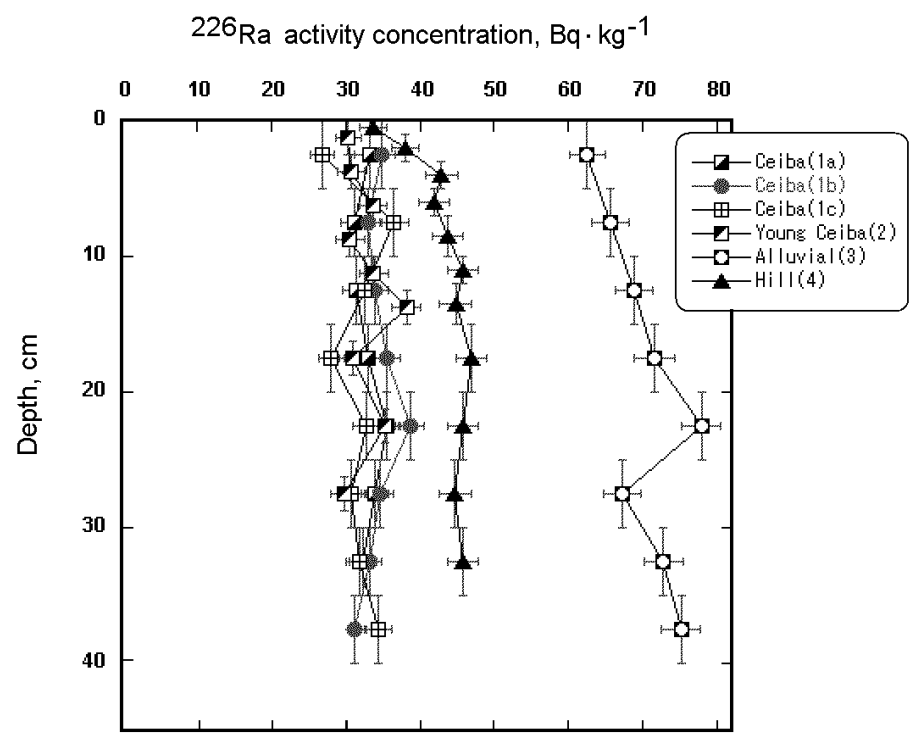

Fig. 3. Depth profiles of ${ }^{226} \mathrm{Ra}$ activity concentration in semi-arid soils from El Angolo (Site 1). Notation in the figure is the same as those in Fig. 1

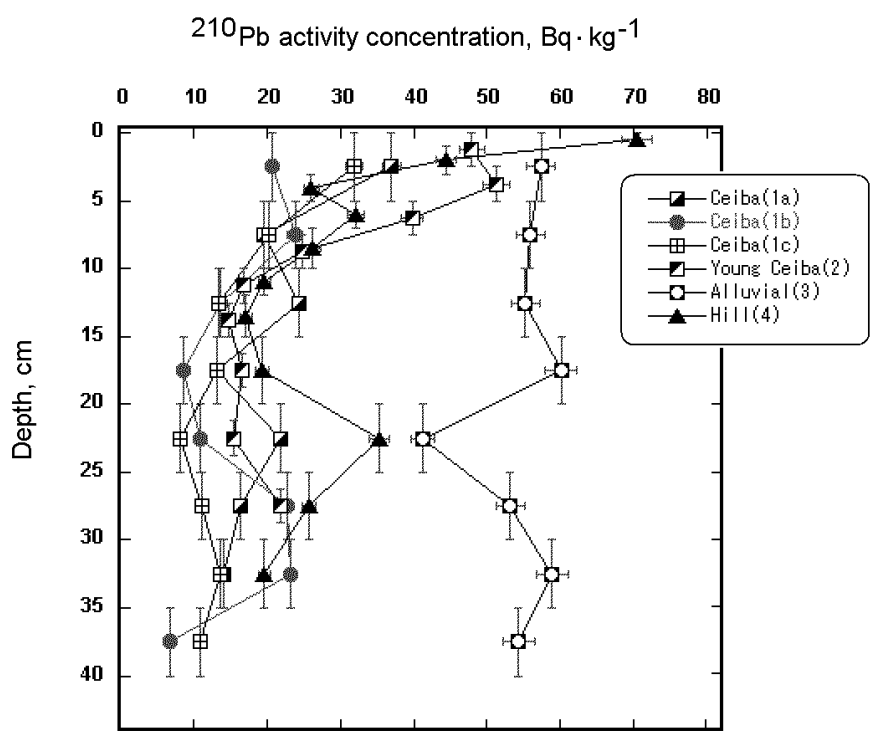

Fig. 4. Depth profiles of ${ }^{210} \mathrm{~Pb}$ activity concentration in semi-arid soils from El Angolo (Site 1) 
Table 2. Mean values of the activity concentration of ${ }^{40} \mathrm{~K},{ }^{137} \mathrm{Cs},{ }^{210} \mathrm{~Pb}$ and ${ }^{226} \mathrm{Ra}$ in several forest soils investigated in the previous studies ${ }^{4,5,7}$

\begin{tabular}{|c|c|c|c|c|}
\hline Site & $\begin{array}{c}{ }^{40} \mathrm{~K} \\
\mathrm{~Bq} \cdot \mathrm{kg}^{-1}\end{array}$ & $\begin{array}{l}{ }^{137} \mathrm{Cs}^{*}{ }^{*} \\
\mathrm{~Bq} \cdot \mathrm{kg}^{-1}\end{array}$ & $\begin{array}{l}{ }^{210} \mathrm{~Pb} \\
\mathrm{~Bq} \cdot \mathrm{kg}^{-1}\end{array}$ & $\begin{array}{l}{ }^{226} \mathrm{Ra}, \\
\mathrm{Bq} \cdot \mathrm{kg}^{-1}\end{array}$ \\
\hline $\begin{array}{l}\text { 1. Sapporo (Japan) } \\
\text { (Cool temperate deciduous stand) }\end{array}$ & 400 & 20 & 180 & 10 \\
\hline $\begin{array}{l}\text { 2. Tharandt (Germany) } \\
\text { (Temperate coniferous stand) }\end{array}$ & $600-800$ & $3-60$ & $60-170$ & $40-50$ \\
\hline $\begin{array}{l}\text { 3. Leinefelde (Germany) } \\
\text { (Temperate deciduous stand) }\end{array}$ & $550-770$ & $60-80$ & $50-120$ & $30-50$ \\
\hline $\begin{array}{l}\text { 4. Lysina (Czech Republic) } \\
\text { (Temperate coniferous stand) }\end{array}$ & $200-1200$ & $10-30$ & $150-600$ & $20-40$ \\
\hline $\begin{array}{l}\text { 5. Pluhuv Bor (Czech Republic) } \\
\text { (Temperate coniferous stand) }\end{array}$ & $180-300$ & $10-20$ & $100-150$ & $15-20$ \\
\hline $\begin{array}{l}\text { 6. Nacetin (Czech Republic) } \\
\text { (Temperate coniferous stand) }\end{array}$ & 400 & 1000 & 400 & 30 \\
\hline
\end{tabular}

* Activity concentration of ${ }^{137} \mathrm{Cs}$ was evaluated at the time of measurements:

1: April-November 2007;

2, 3: April-December 2003;

4-6: December 2004-May 2005.

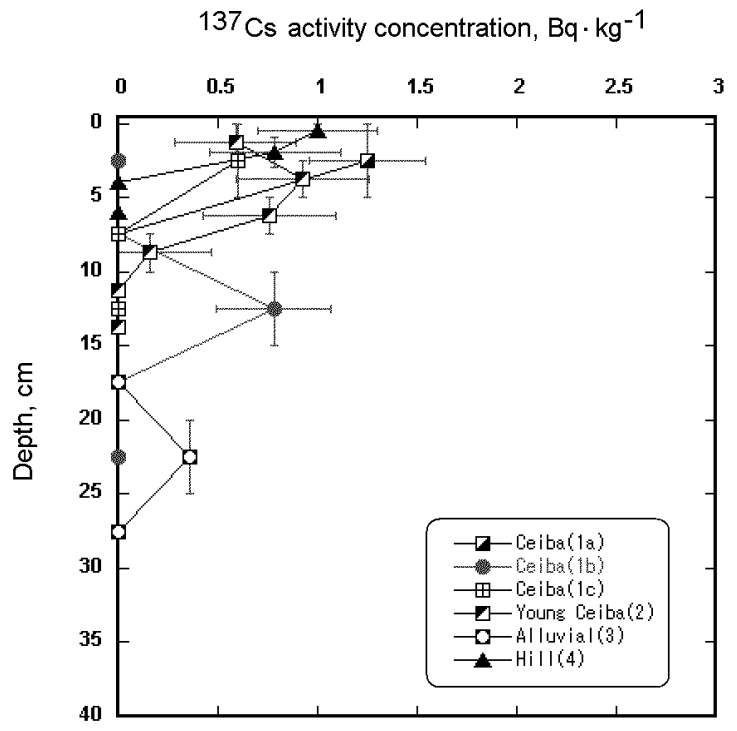

Fig. 5. Depth profiles of ${ }^{137}$ Cs activity concentration in semi-arid soils from El Angolo (Site 1)

As in the case of ${ }^{210} \mathrm{~Pb}$, surface enrichment also appeared at Points 1a and 1c around the Ceiba tree. Similar distribution of ${ }^{137} \mathrm{Cs}$ with depth was found in the literatures in which the highest radiocesium activities were located in the upper $10 \mathrm{~cm}$ of the soil. ${ }^{16}$ In contrast, no radiocesium existed on the surface layer at Point $1 \mathrm{~b}$, but a small maximum appeared about $12 \mathrm{~cm}$ in depth at which the activity concentration was under the detection limit at both Points 1a and 1c. These facts suggest that the soil at Point $1 \mathrm{~b}$ would have been disturbed biologically possibly by burrowing organisms and/or plant rooting. Similar peak in ${ }^{137} \mathrm{Cs}$ activity concentration appears at a depth of about $23 \mathrm{~cm}$ on the riverine sediment at Point 3 . However, as noted before, the anomalies of ${ }^{40} \mathrm{~K},{ }^{226} \mathrm{Ra}$ and ${ }^{210} \mathrm{~Pb}$ concentration observed around at $25 \mathrm{~cm}$ of this river sediment suggest that an unusual natural phenomenon like heavy rain or flood may cause removal or deposition of a great amount of materials all at once. The soil in the hilly site at Point 4 looks undisturbed in the uppermost portion $\left(<10 \mathrm{~cm}\right.$ in depth) with a burial rate of $0.1 \mathrm{~cm} \cdot \mathrm{y}^{-1}$ estimated from both the ${ }^{137} \mathrm{Cs}$ and ${ }^{210} \mathrm{~Pb}$ depth profiles. ${ }^{4}$

While there are still many controversies on low mobility of ${ }^{137} \mathrm{Cs}$ in soil, fallout nuclides including ${ }^{137} \mathrm{Cs}$ are used extensively in erosion and sediment transport studies. Several fallout radionuclides $\left({ }^{241} \mathrm{Am}\right.$, ${ }^{7} \mathrm{Be},{ }^{137} \mathrm{Cs},{ }^{210} \mathrm{~Pb}$ ) were used for evaluating short-term soil mixing on three well-studied landscapes with contrasting climate, geology and vegetation. ${ }^{17}$ Different mixing rates were obtained in different geological sites 
attributing to mechanistic differences in the physical mixing processes. The result was then demonstrated that the widely used model for describing nuclide transport via advection-diffusion processes could not be applicable to one of their sites under coniferous stand in New England, USA. It is consistent with our previous results on coniferous stands in Germany. ${ }^{4}$

\section{Site 2 (Alto Mayo)}

The soil sampling in Alto Mayo was carried out two times: The first sample collected from a heath stand (chamizales) in 2002 was white sandy soil with high acidity and lack of plant-available nutrients in the mineral soil (Photo 2). The second ones were predominantly collected in the vicinity of a cement plant (Pacasmayo) in Moyobamba, Alto Mayo.

Table 3 summarized the results of activity measurements in all the soils. As seen in the table, the ${ }^{40} \mathrm{~K}$ concentration of a sandy soil under tropical heath stand in Alto Mayo was quite small compared with those in El Angolo. There exists a small amount of organic matter in the upper $20 \mathrm{~cm}$ of the soil. ${ }^{2}$ Potassium- 40 was found predominantly in this fraction. The result indicates that the heath plants would have utilized and circulated this potassium for their surviving. Further, it is interested to note that a crack in the soil at a depth of $100 \mathrm{~cm}$ seen in the Photo 2 is reflected in a small peak of ${ }^{40} \mathrm{~K}$ activity concentration.

The activity concentration of ${ }^{137} \mathrm{Cs}$ was also small there $\left(7.5 \mathrm{~Bq} \cdot \mathrm{kg}^{-1}\right)$ even at the surface portion, but it is still higher than those determined in El Angolo semiarid soils.

In contrast, anthropogenic ${ }^{210} \mathrm{~Pb}$ was exceptionally high in concentration $\left(630 \mathrm{~Bq} \cdot \mathrm{kg}^{-1}\right.$ from the surface to $5 \mathrm{~cm}$ in depth). The level is more than 5 times higher than that obtained in Sapporo, Japan (Table 2). ${ }^{5}$

A summary was published on the environment in the Alto Mayo Protected Forest region. ${ }^{9}$ According to this report, the wind primarily originates from the east and from the north during the first three and last three months of the year, respectively. Atomic bomb tests in 1950-1960s were extensively conducted in the atmosphere on the South Pacific Ocean. A great amount of fallout nuclides had been transported with wind over the ocean since then. It is true that about $75 \%$ of the fallout ${ }^{137} \mathrm{Cs}$ present in 1950s had already decayed away in 2002 when the first soil sampling was carried out. Considering the wind direction, ${ }^{9}$ fallout nuclides caused by atomic bomb tests would not have been transported all the way to the tropical forest of Alto Mayo in northern Peru. The question is why only ${ }^{210} \mathrm{~Pb}$, another fallout nuclide, was so high in the same undisturbed soil.
Possible cause might be in an industrial cement production plant and a quarry for the main highway material in New Jerusalem. ${ }^{9}$

In order to elucidate the origin of ${ }^{210} \mathrm{~Pb}$ emission, another soil samples (Points 5, 6 and 7) were collected near the cement plant in March 2006. Location of the point 5 was under shrubby secondary vegetation and close to the quarry for the plant, approximately $800 \mathrm{~m}$ WNW from the factory. The soil was shallow (inceptisol/cambisol), and probably formed on carbonate landslide rock. The Point 6 was the place under higher secondary vegetation, and also close to the quarry of the cement plant, approximately $800 \mathrm{~m}$ from the plant. The soil at Point 6 denoted to cambisol was deeper than that at Point 5. The Point 7 was located in a grass land, approximately $400 \mathrm{~m} \mathrm{NW}$ from the plant. The soil was highly carbon-rich, dark in color resulting from continuous burning of vegetation.

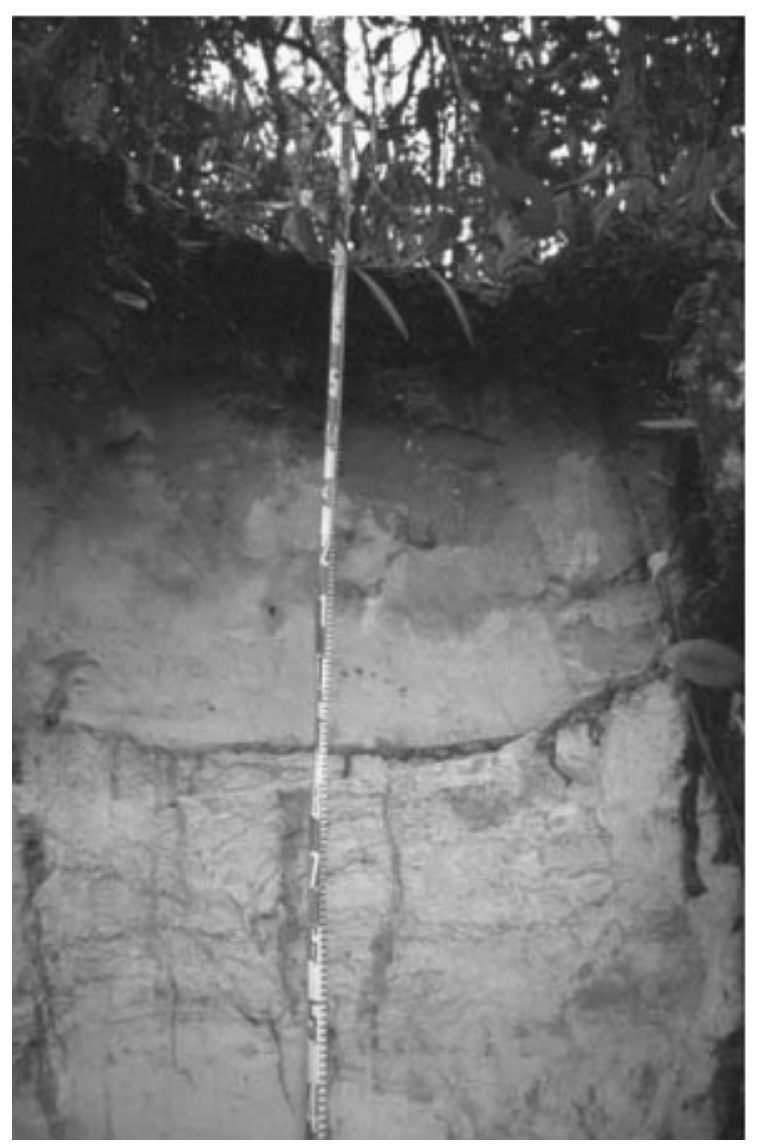

Photo 2. Cross sectional view of acid sand soil under a heath stand in the Alto Mayo (Site 2). Radiopotassium $\left({ }^{40} \mathrm{~K}\right)$ existed only on the uppermost organic rich layer of the soil. A horizontal crack line appearing at a depth of $100 \mathrm{~cm}$ was consistent with a small ${ }^{40} \mathrm{~K}$ peak in its depth profile shown in Table 3 
Table 3. Activity concentration of ${ }^{40} \mathrm{~K},{ }^{137} \mathrm{Cs},{ }^{210} \mathrm{~Pb}$ and ${ }^{226} \mathrm{Ra}$ in soils collected from Alto Mayo, Peru

\begin{tabular}{|c|c|c|c|c|}
\hline $\begin{array}{c}\text { Site } \\
\text { (Depth, cm) }\end{array}$ & $\begin{array}{c}{ }^{40} \mathrm{~K} \\
\mathrm{~Bq} \cdot \mathrm{kg}^{-1} \\
\end{array}$ & $\begin{array}{c}{ }^{137} \mathrm{Cs} \\
\mathrm{Bq} \cdot \mathrm{kg}^{-1} \\
\end{array}$ & $\begin{array}{c}{ }^{210} \mathrm{~Pb} \\
\mathrm{~Bq} \cdot \mathrm{kg}^{-1}\end{array}$ & $\begin{array}{c}{ }^{226} \mathrm{Ra} \\
\mathrm{Bq} \cdot \mathrm{kg}^{-1}\end{array}$ \\
\hline \multicolumn{5}{|l|}{ Alto Mayo } \\
\hline $0-10$ & $72.8 \pm 2.5$ & $7.4 \pm 2.7$ & $617.2 \pm 13.2$ & $31.9 \pm 4.4$ \\
\hline $10-20$ & $23.7 \pm 0.9$ & $2.5 \pm 1.6$ & $571.5 \pm 12.2$ & $6.6 \pm 1.2$ \\
\hline $20-30$ & $0.6 \pm 0.1$ & nd & $41.3 \pm 4.3$ & $18.1 \pm 2.0$ \\
\hline $30-40$ & $4.9 \pm 0.2$ & nd & $33.4 \pm 4.5$ & $23.6 \pm 2.1$ \\
\hline $40-50$ & $0.6 \pm 0.1$ & nd & $22.2 \pm 5.6$ & $20.4 \pm 2.0$ \\
\hline $50-60$ & $0.1 \pm 0.1$ & nd & $12.8 \pm 5.3$ & $19.9 \pm 2.0$ \\
\hline $60-70$ & nd & nd & $31.9 \pm 4.7$ & $35.3 \pm 2.6$ \\
\hline $70-80$ & nd & nd & $25.1 \pm 4.9$ & $19.9 \pm 2.0$ \\
\hline $80-90$ & $3.4 \pm 0.2$ & nd & $25.9 \pm 4.6$ & $14.9 \pm 1.7$ \\
\hline $90-100$ & $12.1 \pm-.4$ & nd & $30.9 \pm 4.8$ & $24.5 \pm 2.3$ \\
\hline $100-110$ & nd & nd & $34.4 \pm 4.7$ & $34.6 \pm 2.6$ \\
\hline \multicolumn{5}{|l|}{ Moyobamba } \\
\hline \multicolumn{5}{|l|}{ Point 5} \\
\hline $0-5$ & $867.4 \pm 11.8$ & $7.4 \pm 0.5$ & $349.6 \pm 6.3$ & $129.7 \pm 3.6$ \\
\hline $5-10$ & $1024 \pm 12.1$ & $5.8 \pm 0.5$ & $190.8 \pm 4.5$ & $149.3 \pm 3.5$ \\
\hline $10-15$ & $1120 \pm 12.7$ & $2.9 \pm 0.4$ & $153.3 \pm 4.1$ & $161.9 \pm 3.6$ \\
\hline $15-20$ & $1132 \pm 12.7$ & $1.6 \pm 0.4$ & $109.8 \pm 3.4$ & $162.2 \pm 3.6$ \\
\hline \multicolumn{5}{|l|}{ Point 6} \\
\hline $0-5$ & $492.9 \pm 8.1$ & $2.7 \pm 0.4$ & $284.9 \pm 5.4$ & $137.5 \pm 3.4$ \\
\hline $5-10$ & $539.7 \pm 8.2$ & $3.8 \pm 0.4$ & $191.4 \pm 4.4$ & $147.1 \pm 3.3$ \\
\hline $10-15$ & $552.3 \pm 7.9$ & $0.9 \pm 0.3$ & $123.4 \pm 3.4$ & $147.8 \pm 3.2$ \\
\hline $15-20$ & $613.4 \pm 8.3$ & nd & $101.9 \pm 3.1$ & $154.4 \pm 3.2$ \\
\hline $20-25$ & $650.2 \pm 8.6$ & nd & $113.8 \pm 3.3$ & $148.6 \pm 3.2$ \\
\hline \multicolumn{5}{|l|}{ Point 7} \\
\hline $0-5$ & $106.8 \pm 2.7$ & $0.7 \pm 0.3$ & $52.6 \pm 1.6$ & $48.4 \pm 2.1$ \\
\hline $5-10$ & $94.2 \pm 2.4$ & nd & $32.4 \pm 1.2$ & $51.4 \pm 2.2$ \\
\hline $10-15$ & $93.4 \pm 2.4$ & nd & $33.7 \pm 1.1$ & $48.7 \pm 2.0$ \\
\hline $15-20$ & $91.2 \pm 2.4$ & nd & $31.8 \pm 1.3$ & $44.6 \pm 1.9$ \\
\hline $20-25$ & $87.2 \pm 2.3$ & nd & $38.7 \pm 1.3$ & $47.4 \pm 2.0$ \\
\hline $25-30$ & $98.5 \pm 2.6$ & nd & $34.5 \pm 1.4$ & $53.9 \pm 2.0$ \\
\hline $30-35$ & $103.9 \pm 2.6$ & nd & $42.0 \pm 1.5$ & $60.6 \pm 2.3$ \\
\hline $35-40$ & $111.3 \pm 2.8$ & nd & $49.7 \pm 1.6$ & $62.8 \pm 2.2$ \\
\hline
\end{tabular}

Mean value \pm standard deviation $(n=3)$

Minimum detectable activity (MDA) of ${ }^{40} \mathrm{~K},{ }^{137} \mathrm{Cs},{ }^{210} \mathrm{~Pb}$ and ${ }^{226} \mathrm{Ra}$ are $0.63,0.31,0.59$ and $0.33 \mathrm{~Bq}$ in a typical soil sample ( $100 \mathrm{~g}, 48 \mathrm{hrs}$ counting time, HPGE detector), respectively.

nd: Under the detection value for each nuclide.

As shown in Table 3, the ${ }^{137} \mathrm{Cs}$ concentration was very small, especially in the soil collected from Segunda Jerusalen (Point 7) which contained little radiocesium even in the uppermost layer. With respect to the ${ }^{210} \mathrm{~Pb}$ profiles, the soil from Segunda Jerusalen (Point 7) was quite different with those at Points 5 and 6 collected in other places of Moyobamba. Soil at Point 7 did not show surface enrichment for both nuclides. The ${ }^{210} \mathrm{~Pb}$ concentration was virtually the same from the surface down to a depth of $40 \mathrm{~cm}$ at Point 7 . Such a depth profile of the fallout nuclide may reflect possible intervention to the soil by men at least down to this depth like plowing. In contrast, ${ }^{210} \mathrm{~Pb}$ concentration was exceptionally high in the soils from the Points 5 and 6 in Moyobamba, especially in the upper $10 \mathrm{~cm}$ in depth.
Difference in the activity level of both fallout nuclides may be explained by considering different sources releasing each nuclide. Considering the fact that the ${ }^{137} \mathrm{Cs}$ concentration is also very low in El Angolo (Fig. 5), global fallout of this nuclide may not be so serious in the study areas of northern Peru compared with the places having been investigated in northern hemisphere. In contrast, there may be local source(s) emitting ${ }^{210} \mathrm{~Pb}$ to the atmosphere, since the ${ }^{210} \mathrm{~Pb}$ level in El Angolo was not high (Fig. 4). It should be noted that the ${ }^{210} \mathrm{~Pb}$ concentration was found to be very small $\left(<\mathrm{a}\right.$ few $\left.\mathrm{Bq} \cdot \mathrm{kg}^{-1}\right)$ both in carbonates and cement products collected in the vicinity of the cement plant "Pacasmayo". However, a sample of coal used in this factory contained appreciable amount of ${ }^{210} \mathrm{~Pb}$ 
$\left(50 \mathrm{~Bq} \cdot \mathrm{kg}^{-1}\right)$. Burning of local coal may become a source of ${ }^{210} \mathrm{~Pb}$ (and other lead isotopes), because it is a fallout nuclide derived from the atmosphere. Further study is necessary to specify the emission source of this nuclide in Alto Mayo region in order to protect the natural environment in Northern Peru.

The findings in this study suggest that anthropogenic nuclides $\left({ }^{137} \mathrm{Cs}\right.$ and $\left.{ }^{210} \mathrm{~Pb}\right)$ will be useful for tracing possible sources of pollutants released to the atmosphere. ${ }^{18}$

\section{Conclusions}

Depth profiles of environmental radionuclides suggest that semi-arid and montane tropical soils in northern Peru were intervened both naturally and anthropogenically. Natural intervention includes biological activities such as root uptake of the nutrients and movement of various organisms like earthworms and moles. Different ${ }^{40} \mathrm{~K}$ profiles obtained around a Ceiba tree in El Angolo may result from root uptake of the nutrients for a long time. Influence of global fallout due to atomic bomb tests in 1950-1960s would not have been so serious in the study sites of both El Angolo and Alto Mayo. However, local human activities like burning fossil fuels may have subtle effects on vulnerable natural soil environment, especially in Alto Mayo.

\section{$*$}

The present work was supported by the Japan Securities Scholarship Foundation in 2005-2006. The traveling fee was covered by the Hayashi Memorial Foundation for Female Natural Scientists in 2005-2006. The authors would like to thank Viviana HoRNA (University of Göttingen, Germany) for the opportunity to visit and collect soil samples in the El Angolo reserve. They greatly thank Pedro VASQuEZ (Universidad Nacional Agraria La Molina, Peru) for the helpful field support, and logistical support in Lima provided by the family Julio HORNA.

\section{References}

1. H. TREIDEL, Geomorphologic Feature, Soils and Vegetation of the Central Cordillera Cahuapanas (Alto Mayo, Peru). Diploma Thesis in Geoecology, University of Bayreuth, Bayreuth, Germany, 2004.

2. J. DiETZ, Variation and Distribution of Forest Types on the Southern Foothills of the Cordillera Cahuapanas, Alto Mayo, Peru, Diploma Thesis, University of Bayreuth, Bayreuth, Germany, 2002.

3. R. Zimmermann, H. S. Roque, A. Borner, T. Mette, Conservation of Biodiversity in the Andes and the Amazon, INKA, Munich, Germany, 2002, p. 327.

4. R. Fujiyoshi, S. Sawamura, Sci. Total Environ., 320 (2004) 177.

5. R. Fujiyoshi, M. Kinoshita, S. SAwamura, Environ. Geochem. Health, 27 (2005) 539.

6. R. Fujiyoshi, K. Sakamoto, T. Imanishi, T. Sumiyoshi, S. SAWAmura, J. Vaupotic, I. Kobal, Sci. Total Environ., 370 (2006) 224.

7. R. Fujiyoshi, Y. Satake, T. Sato, T. Sumiyoshi, S. SAWAMURA, Environ. Chem., an Indean J., 2(1) (2007), Web publication (http://www.tsijournals.com/esaij).

8. World Wildlife Fund (WWF) and Fundacion Peruana para la Conservacion de la Naturaleza (FPCN), World Wildlife Fund-US, Washington, DC. USA, 1988, p. 305.

9. A. Lainez, M. Moncada, T. Gomez, Protected Area ProfilePeru Alto Mayo Protected Forest, 2003, www.parkswatch.org

10. B. P. Albers, R. Rackwitz, S. Kleinschroth, K. Bunzl, Trace Elements, Elsevier, Amsterdam, The Netherlands, 2000, p. 537.

11. D. E. Walling, Q. He, Soil Sci. Soc. Am. J., 63 (1999) 1404.

12. P. BosSEW, G. KIRCHNER, J Environ. Radioact., 73 (2004) 127.

13. S. Roussel-Debel, P. Renaud, J-M. Metivier, Sci. Total Environ., 375 (2007) 388.

14. UNSCEAR, Sources and Effects of Ionizing Radiation, United Nations Scientific Committee on the Effects of Atomic Radiation, Report, 2000.

15. P. Bossew, F. StRebl, J. Environ. Radioact., 53 (2001) 199.

16. S. Kruse-Irmer, L. Giani, J. Plant Nutr. Soil Sci., 166 (2003) 635 .

17. J. M. Kaste, A. M. Heimsath, B. C. Bostick, Geology, 3 (2007) 243.

18. R. A. Aliev, V. A. Bobrov, N. Kalmykov, M. S. Melgunov, I. E. Vlasova, V. P. Shevchenko, A. N. Novigatsky, A. P. LisitZIN, J. Radioanal. Nucl. Chem., 274 (2007) 315. 